\title{
PENGARUH PENGGUNAAN MODEL PEMBELAJARAN KOOPERATIF TIPE TIME TOKEN PADA MATERI ATMOSFER TERHADAP HASIL BELAJAR DAN MOTIVASI BELAJAR SISWA KELAS X DI SMA NEGERI 3 BANJAR
}

\author{
Agung Wahyudi \\ Jurusan Pendidikan Geografi, Fakultas Keguruan dan Ilmu Pendidikan, Universitas Siliwangi \\ agungwhy3@gmail.com
}

\begin{tabular}{lr}
\hline \multicolumn{2}{c}{ INFO ARTIKEL } \\
\hline Riwayat Artikel $:$ \\
Dikirim $\quad: 13-04-2020$ \\
Disetujui $\quad: 26-05-2020$ \\
Diterbitkan $:$ 10-06-2020 \\
\hline
\end{tabular}

Kata Kunci :

Kooperatif tipe time token, Hasil Belajar, Motivasi

Belajar

\section{ABSTRAK}

Abstract: The background of this research is the low learning outcomes and learning motivation of class $X$ students at SMA Negeri 3 Banjar on geography subjects. This study aims to determine the effect of the type of time token cooperative learning model on learning outcomes and motivation to learn geography of atmospheric material. The method used in the form of experiments with data collection techniques such as Observation, Questionnaires, Interviews, Documentation, Literature studies, and testsThe results of the cooperative learning model type time token affect the learning outcomes and learning motivation in geographic subjects of atmospheric material based on the results of paired sample ttests with a value of $t$ calculated 13,510 learning outcomes and 9,334 learning motivation is greater than t table 2.0432, and sig value 0.00 $<0.05$.

\begin{abstract}
Abstrak: Latar belakang penelitian ini adalah rendahnya hasil belajar dan motivasi belajar siswa kelas X di SMA Negeri 3 Banjar pada mata pelajaran geografi. Penelitian ini bertujuan untuk mengetahui pengaruh model pembelajaran kooperatif tipe time token terhadap hasil belajar dan motivasi belajar mata pelajaran geografi materi atmosfer. Metode yang digunakan berupa eksperimen dengan teknik pengumpulan data berupa Observasi, Kuisioner, Wawancara, Dokumentasi, Studi literatur, dan tes. Hasil penelitian model pembelajaran kooperatif tipe time token berpengaruh terhadap hasil belajar dan motivasi belajar pada mata pelajaran geografi materi atmosfer berdasarkan hasil uji paired sample $t$ tes dengan nilai t hitung hasil belajar 13.510 dan motuvasi belajar 9.334 nilai tersebut lebih besar dari t tabel 2.0432, serta nilai sig 0,00<0,05.
\end{abstract}

\section{PENDAHULUAN}

Pendidikan merupakan proses yang sangat penting dalam kehidupan manusia baik bagi individu itu sendiri maupun bangsa dan negara. Secara umum pendidikan merupakan transfer pengetahuan yang dilakukan oleh seorang pendidik kepada peserta didik lewat sebuah pembelajaran yang dilakukan secara formal. Pembelajaran adalah membelajarkan siswa menggunakan asas pendidikan maupun teori belajar yang merupakan penentu utama keberhasilan pendidikan. Pembelajaran merupakan proses komunikasi dua arah (Sagala, 61:2009). Proses pembelajaran berpengaruh terhadap hasil belajar yang didapat oleh seorang peserta didik. Keberhasilan seorang pendidik tidak terlepas dari suatu model pembelajaran yang diterapkan serta media yang digunakan sehingga dapat 
menciptakan suasana pembelajaran interaktif yang berjalan dua arah.

Pada kurikulum 2013 setiap pendidik diharuskan memiliki kemampuan mengembangkan model pembelajaran agar proses pembelajaran yang dilakukan pendidik tidak hanya berjalan satu arah (teacher centre). Proses pembelajaran dapat berjalan dua arah atau berpusat kepada peserta didik (student centre) sehingga proses pembelajaran menjadi lebih interaktif. Mata Pelajaran Geografi merupakan mata pelajaran yang perlu menerapkan perlakuan khusus sehingga peserta didik dapat lebih tertarik dan termotivasi dalam proses pembelajaran. Salah satu model pembelajaran kooperatip (cooperative learning) yang membuat siswa aktif yaitu model pembelajaran kooperatip tipe time token.

Model time token pertama kali diperkenalkan oleh Arends pada tahun 1998 model pembelajaran time token merupakan model pembalajaran yang bertujuan agar masing-masing anggota kelompok diskusi mendapatkan kesempatan untuk memberikan konstribusi mereka dan mendengarkan pandangan serta pemikiran anggota lain (Aqib, 2014:33). Model pembelajaran berdiskusi saat ini telah banyak berkembang dengan berbagai variasi namun, yang membedakan model berdiskusi time token dengan model berdiskusi yang lain adalah dengan kartu bicara yang menjadi ketepatan waktu dalam menyampaikan pendapat ketika berdiskusi, time token itu sendiri berasal dari kata time artinya waktu dan token artinya tanda.

Model pembelajaran kooperatif tipe time token merupakan sebuah model pembelajaran yang diaplikasikan dengan cara pemberian tugas yang ditulis dalam sebuah kupon yang dibuat sedemikian rupa dan peserta didik diberi waktu untuk menjelaskan materi yang terdapat pada kupon tersebut. Model pembelajaran model time token merupakan model yang dijalankan oleh guru dengan cara pembentukan kelompok dan pemberian kupon serta memberikan kesempatan kepada seluruh siswa untuk menjelaskan serta menyampaikan pendapat materi dengan durasi waktu yang telah ditentukan. Penggunaan model pembelajaran kooperatif tipe time token mampu meningkatkan kemampuan bicara serta menjadikan peserta didik menjadi demokartis sehingga peserta didik dapat termotivasi dalam proses belajar. Bagi guru model pembelajaran kooperatif tipe time token dapat membantu dan mengembangkan proses belajar mata pelajaran geografi dikelas yang memiliki permasalahan terutama masalah yang berkaitan dengan hasil belajar dan motivasi belajar.

Hasil belajar adalah pola-pola perbuatan, nilai-nilai, pengertian-pengertian, sikap sikap, apresiasi dan keterampilan. Motivasi Belajar adalah dorongan internal dan eksternal pada siswa-siswa yang sedang belajar untuk mengadakan perubahan tingkah laku, pada umumnya dengan beberapa indikator atau unsur yang mendukung Uno (2009:23)

Berdasarkan penelitian dilapangan, ditemukan fakta bahwa motivasi belajar siswa di kelas X IPS SMA Negeri 3 Banjar Tahun Pelajaran 2019/2020 masih belum sesuai dengan yang diharapkan. Hal tersebut dapat diketahui dalam suatu proses pembelajaran yang kurang interaktif dan pembelajaran yang masih didominasi oleh sebagian siswa serta hasil belajar yang belum maksimal. Perolehan nilai Mata Pelajaran Geografi yang didapat oleh peserta didik 50\% diantaranya masih berada dibawah Kriteria Ketuntasan Minimal (KKM), yang ditetapkan sebesar 75. Siswa hanya mampu memperoleh nilai berkisar antara 50 sampai 65, sehingga perlu adanya penerapan model pembelajaran yang sesuai. Penerapan model pembelajaran kooperatif tipe time token diharapkan dapat membantu siswa untuk menumbuhkan motivasi belajar sehingga terjadi suatu proses peningkatan dalam pembelajaran menjadi lebih interaktif dan mencapai tujuan belajar.

Rumusan masalah dalam penelitian ini 1) Bagaimanakah pengaruh penggunaan model pembelajaran kooperatif tipe time token terhadap hasil belajar dan motivasi belajar Mata Pelajaran Geografi materi Atmosfer pada siswa kelas X di SMA Negeri 3 Banjar

Tujuan dilakukannya penelitian 1) mengetahui pengaruh model pembelajaran kooperatif tipe time token terhadap hasil belajar dan motivasi belajar Mata Pelajaran Geografi materi atmosfer

\section{METODE PENELITIAN}

Metode yang digunakan dalam penelitian ini adalah metode eksperimen. Desain yang digunakan adalah "Pretest-Posttest group control design" 
Populasi dari penelitian ini adalah seluruh siswa kelas $\mathrm{X}$ yang terdiri dari 10 kelas dengan jumlah siswa sebanyak 340 orang siswa. Sampel dalam penelitian ini yaitu peserta didik kelas X IPS 3 (kelompol eksperimen) dengan jumlah 35 peserta didik dan kelas X IPS 4 (kelompol kontrol) dengan jumlah 35 peserta didik. Teknik pengambilan sampel dalam penelitian ini dengan menggunakan probability sampling dengan teknik simple random sampling.

Teknik analisis data dilakukan dengan bantuan sofware SPSS 16.0 for window dengan langkah-langkah: 1) pengujian persyaratan analisis dengan uji normalitas dengan menggunakan metode Kolmogotov-smirnov untuk uji homogenitas dengan dilakukan dengan uji levene test, dan untuk pengujian hipotesis dilakukan dengan uji paired sample $t$ test.

\section{HASIL DAN PEMBAHASAN}

\section{Data Hasil Belajar}

Data pretes kelompok kontrol dan eksperimen

Pretes dilakukan pada awal pembelajaran dengan tujuan mengetahui kemampuan awal sebelum melaksanakan pembelajaran serta menjadi perbandingan anatara sebelum dan sesudah melakukan treatment. Pengolahan data dilakukan dengan membagi kedalam tiga kategori yaitu tinggi, sedang dan rendah. Berdasarkan analisis deskriptif data sebagai berikut: pada kelompok kontrol diperoleh hasil pada kategori tinggi $=$ $32 \%$, sedang $=34 \%$, rendah $=34 \%$. Sementara kelompok eksperimen pada kategori tinggi $=$ $23 \%, \quad$ sedang $=63 \%$, rendah $=14 \%$. Berdasarkan data tersebut dapat disimpulkan bahwa hasil pretes untuk kelompok kontrol antara kategori rendah-tinggi relatif seimbang dan untuk kelompok eksperimen lebih dominan pada kategori sedang, jika dilihat dari kategori tinggi selisih antara kelompok kontrol dan eksperimen yaitu sebesar 9\% .

\section{Data postes kelompok kontrol dan eksperimen}

Postes dilakukan dengan tujuan mengetahui perubahan antara sebelum dan sesudah melakukan pembelajaran. Pada kelompok kontrol pembelajaran dilakukan dengan metode konvensional sedangkan pada kelompok eksperimen menggunakan model pembelajaran kooperatif tipe time token. Pengolahan data dilakukan dengan membagi kedalam tiga kategori yaitu tinggi, sedang dan rendah. Berdasarkan analisis deskriptif data sebagai berikut: pada kelompok kontrol diperoleh hasil pada kategori tinggi $=34 \%$, sedang $=49 \%$, rendah $=17 \%$ dan untuk kelompok eksperimen kategori tinggi $=37 \%$, sedang $=52 \%$, rendah $=11 \%$. Berdasarkan data tersebut maka dapat disimpulkan terjadi perubahan pada setiap kategori baik pada kelompok kontrol maupun eksperimen, jika dilihat pada kategori tinggi kenaikan yang terjadi pada kelas eksperimen lebih tinggi yaitu sebesar $14 \%$ meskipun selisih antara kelompok kontrol dan eksperimen tidak terlalu signifikan.

\section{Data motivasi kelompok kontrol dan eksperimen}

Pengambilan data motivasi belajar dilakukan bersamaan dengan pelaksanaan postes. Pengolahan data dilakukan dengan membagi kedalam tiga kategori yaitu tinggi,sedang dan rendah. Berdasarkan analisis deskriptif data sebagai berikut: pada kelompok kontrol diperoleh hasil pada kategori tinggi $=$ $29 \%$, sedang $=42 \%$ rendah, $29 \%$ dan untuk kelompok eksperimen kategori tinggi $=46 \%$, sedang $=31 \%$, rendah $=23 \%$. Berdasarkan data tersebut maka dapat disimpulkan bahwa kelompok eksperimen dengan dengan menggunakan model pembelajaran kooperatif tipe time token lebih baik daripada kelompok kontrol dengan model konvensional jika dilihat berdasarkan kategori tinggi. Selisih antara kelompok kontrol dengan eksperimen sebesar $17 \%$.

Analisi data menggunakan dengan uji paired sample t-test dengan tujuan membandingkan antara nilai pretes dengan postest. Pada tahap awal dilakukan analisis uji normalitas dengan menggunakan uji Kolmogorov-Smirnov, dengan bantuan program SPSS 16.0 for Windows, dilanjutkan dengan uji homogenitas dengan uji Levane. Berdasarkan uji normalitas data yang disajikan pada tabel 1 sebagai berikut: 
Tabel 1. Hasil Uji Normalitas Data

\begin{tabular}{lcccc}
\hline \multirow{2}{*}{\multicolumn{1}{c}{ Data }} & \multicolumn{3}{c}{ Kolmogorov- Smirnov } & \multirow{2}{*}{ Kesimpulan } \\
\cline { 2 - 4 } & Statistic & Df & Sig. (p) & \\
\hline Skor Pretest kelas kontrol & .125 & 35 & .180 & Normal \\
Skor Pretest kelas eksperimen & .096 & 35 & .200 & Normal \\
Skor Postest kelas kontrol & .128 & 35 & .157 & Normal \\
Skor Postest kelas eksperimen & .084 & 35 & .200 & Normal \\
Skor Motivasi Kelas Kontrol & .126 & 35 & .173 & Normal \\
Skor Motivasi Kelas eksperimen & .106 & 35 & .200 & Normal \\
\hline
\end{tabular}

Sumber : Penelitian 2020

Tabel 2. Hasil Uji Homogenitas Data

\begin{tabular}{cccc}
\hline Data & Levene Statistic & Sig & Kseimpulan \\
\hline Hasil Belajar & 2.008 & .161 & Homogen \\
Motivasi Belajar & .151 & .698 & Homogen \\
\hline
\end{tabular}

Sumber : Penelitian 2020

Tabel 3. Hasil Uji Paired Sample t-test

\begin{tabular}{cccc}
\hline Variabel & T Hitung & T Tabel & Sig \\
\hline Hasil Belajar & 13.510 & 2.0432 & .000 \\
Motivasi Belajar & 9.334 & 2.0432 & .000 \\
\hline
\end{tabular}

Sumber : Penelitian 2020

Berdasarkan data pada tabel 1, semua data baik pretes dan postes,serta kedua data motivasi dari kedua kelompok memperoleh nilai Sig > 0,05. yang artinya Ho diterima dan data berdistribusi normal. Selanjutnya dilakukan uji homogenitas dari kedua data tersebut diperoleh data pada tabel 2 . Berdasarkan data hasil analisis uji Lavene pada tabel 2, semua data antara hasil belajar dengan motivasi belajar kedua data tersebut lebih besar dari nilai sig 0,05 dengan demikian kedua data tersebut homogen. Selanjutnya untuk mengetahui pengaruhnya melakukan uji paired sample t-test diperoleh data pada tabel 3.

Dari data diatas diketahui bahwa nilai $\mathrm{t}$ hitung untuk hasil belajar 13.510 dan untuk motivasi belajar 9.334 artinya kedua data tersebut > nilai t tabel 2.0432 artinya Ha diterima, Ho ditolak. Berdasarkan nilai signifikasi (sig) diperoleh data $.000<0,0505$ sesuai dengan pengambilan keputusan dalam paired sample t-test maka maka Ho ditolak Ha diterima. Maka dapat disimpulkan bahwa pembelajaran dengan menggunakan model kooperatif tipe time token berpengaruh terhadap hasil belajar dan motivasi belajar pada materi atmosfer.

\section{SIMPULAN}

Berdasarkan hasil penelitian yang telah dikemukakan pada bab sebelumnya maka dapat disimpulkan bahwa 1) terdapat perbedaan hasil belajar antara siswa yang mendapatkankan pembelajaran kooperatif tipe time token dengan siswa yang mendapatkan pembelajaran konvensional. 2) ) terdapat perbedaan motivasi belajar antara siswa yang mendapatkankan pembelajaran kooperatif tipe time token dengan siswa yang mendapatkan pembelajaran konvensional.

\section{REKOMENDASI}

1. Perlu adanya penelitian lanjutan mengenai model-model pembelajaran kooperatif untuk meningkatkan motivasi belajar siswa

2. Model pembelajaran kooperatif tipe time token dapat menjadi alternatif untuk meningkatakan motivasi belajar siswa.

\section{DAFTAR PUSTAKA}

A.M, Sardiman. 2007. Interaksi dan Motivasi Belajar Mengajar. Bandung: Rajawali Pers.

Aqib, Zaenal. 2013. Model-Model, Media dan Strategi Pembelajaran Kontekstual (inofatip), Bandung: Yratma widya. 
Sudayana, Rostiana. 2013. Statistika Penelitian Pendidikan. Garut: STIKIP GARUT.

Sugiyanto. 2010. Model-model Pembelajaran Inovatif. Surakarta: Yuma Pustaka.

Sugiyono. 2017. Metode Penelitian Kuanitatif, Kualitatif dan R\&D. Bandung: Alfabeta.
Uno, Hamzah B. 2009. Teori motivasi dan Pengukurannya (Analisis di Bidang Pendidikan). Jakarta: Bumi Aksara.

Uno, H. dan Nurdin. 2015. Belajar dengan pendekatan PAILKEM. Jakarta: Bumi Aksara. 